\title{
WATER QUALITY AND HEAD LOSS IN IRRIGATION FILTERS
}

\author{
Túlio Assunção Pires Ribeiro"*; José Euclides Stipp Paterniani²; Rogério Pereira da Silva \\ Airoldi²; Marcelo Jacomini Moreira da Silva ${ }^{2}$ \\ ${ }^{1}$ UNICAMP/FEAGRI - Depto. de Água e Solo na Área de Qualidade da Água para Irrigação, CP. 6011 - \\ 13083-970 - Campinas, SP - Brasil. \\ 2 UNICAMP/FEAGRI - Depto. de Água e Solo. \\ *Corresponding author <tulior@agr.unicamp.br>
}

\begin{abstract}
Among the irrigation systems used today, trickle irrigation is one of the most efficient methods. This research, conducted by means of field tests, had the objective of comparing head loss evolution on water filtration with a disc filter $(130 \mu \mathrm{m})$ and a non-woven synthetic fabric filter used in a drip irrigation system. The test consisted of fertirrigation with organic fertilizer, and chemical treatment of the water with sodium hypochlorite. Physical, chemical, and biological parameters were analyzed, such as: $\mathrm{pH}$, turbidity, suspended solids, dissolved solids, EC, hardness, Langelier index, total iron, manganese, sulfides, algae, and bacteria. The water source used in this experiment was from an open reservoir, where an experimental trickle irrigation system had been installed. The research was developed in four steps lasting 30 days each, during different seasons. The chemical factors $\mathrm{pH}$, total iron, and concentration of sulfides presented a medium risk of clogging the emitters. All other physical and biological water quality parameters analyzed resulted in values that did not present an emitter-clogging risk. There was a correlation of results between physical parameters turbidity, suspended solids, and algae, and suspended solids. Fertirrigation influenced water quality. The concentration of free chlorine was higher in the effluent from the disc filter. Head loss evolution in the non-woven synthetic fabric filter was more striking and faster than in the disc filter.
\end{abstract}

Key words: drip irrigation, filtration, chlorine, non-woven synthetic fabric, fertilizers

\section{QUALIDADE DA ÁGUA E PERDA DE CARGA EM FILTROS DE IRRIGAÇÃO}

\begin{abstract}
RESUMO: Dentre os sistemas de irrigação atualmente utilizados, a irrigação por gotejamento é um dos métodos mais eficientes. Este trabalho teve como objetivo fazer uma investigação experimental para comparar a evolução da perda de carga dos meios filtrantes disco $(130 \mu \mathrm{m})$ e manta sintética não tecida na filtragem da água, utilizados em um sistema de irrigação por gotejamento. Nesta comparação utilizou-se a técnica da fertirrigação com fertilizante orgânico e um tratamento químico da água com o hipoclorito de sódio. Durante um ano analisou-se a variação temporal, dos principais parâmetros físicos, químicos e biológicos da água de irrigação que causam problemas de entupimentos nos emissores. Os parâmetros analisados foram: sólidos suspensos, turbidez, $\mathrm{pH}$, ferro, manganês, sulfetos, condutividade elétrica, sólidos dissolvidos, dureza, índice de Langelier, algas e bactérias. Utilizou-se água de um reservatório aberto, onde foi instalado um módulo de irrigação localizada para o estudo. A pesquisa foi desenvolvida em quatro etapas de 30 dias, realizadas em diferentes estações do ano. Os parâmetros químicos $\mathrm{pH}$, ferro e sulfetos apresentaram médio risco de obstrução aos emissores. Os parâmetros físicos e biológicos analisados apresentaram baixo risco de entupimento dos emissores. Houve correlação dos resultados entre os parâmetros turbidez e sólidos suspensos totais e algas com sólidos suspensos totais. A fertirrigação influenciou a qualidade da água. A concentração de cloro livre foi maior no efluente do filtro de disco. No filtro de manta sintética não tecida a evolução da perda de carga foi mais acentuada e mais rápida em relação ao de disco.

Palavras-chave: gotejamento, filtragem, cloro, manta sintética não tecida, fertilizantes
\end{abstract}

\section{INTRODUCTION}

Among the irrigation systems used today, trickle irrigation is one of the most efficient methods. A frequent problem in this type of irrigation system is the clogging of emitters, which is directly related to water quality and filtering system efficiency. Normally, obstructions are caused by a combination of physical, chemical, and bio- logical factors present in the irrigation water, such as the presence of clay and corrosion products enclosed within a biological mass and cemented with $\mathrm{CaCO}_{3}$ precipitates. However, the greatest clogging problems are caused by the presence of suspended materials, such as silt, algae, etc. (Adin \& Alon, 1986). In the particular case of algal and bacterial growth in springs used for water collection and inside irrigation system pipes, the situation is wors- 
ened due to the practice of fertirrigation, an increasingly used technique in trickle irrigation systems.

Filtering mechanisms can be divided into screen and disc filters, classified as mechanical or surface filter elements, where the filtering process is based on the principle according to which the pores of the filtering medium are smaller than the diameter of the particles that have to be filtered; and as granular or sand filters, where the particles that must be retained are smaller than the pores of the filter element, but retention of these particles is achieved by physical and chemical processes (Adin \& Alon, 1986).

Experimental assays in the field have compared the filtering efficiency between $130-\mathrm{mm}$ disc and screen filter elements, and non-woven synthetic fabric filter elements. The fabric was more efficient than the screen and disc elements, removing a larger amount of suspension solids and algae that were present in the irrigation water; however, head loss developed more rapidly in the fabric filter as a function of filtered volume (Scatolini, 2001).

In this work, comparisons were made by means of field assays to determine head loss evolution as a function of volume filtered by two filters: a disc filter $(130 \mu \mathrm{m})$ and a non-woven synthetic fabric filter, during one year, in a drip irrigation system. The fertirrigation technique was used with application of chlorine during irrigation, in the form of sodium hypochlorite. In this comparison, variations of physical, chemical, and biological nature present in the irrigation water were also studied throughout the year, which could cause emitter clogging problems. A study concerning the influence of fertirrigation on irrigation water quality was also conducted.

\section{MATERIAL AND METHODS}

The experiment was conducted in the municipality of Campinas, State of São Paulo, Brazil. The criteria adopted to evaluate impurities present in irrigation water were based on studies performed by Nakayama \& Bucks (1986). The water used in the experiment came from a $250 \mathrm{~m}^{3}$ reservoir, consisting of a small weir supplied with water pumped from a small dam that received water contributions from other springs around it.

\section{Equipment}

An irrigation system was set up in the experimental area, consisting of an electric-powered centrifugal pump, an automatic irrigation controlling device, two electrical valves with solenoids, drip emitters, two differential pressure transducers, two pressure regulators, three turbine-type digital water meters in the flow range from 0.6 to $6 \mathrm{~m}^{3} \mathrm{~h}^{-1}$, two Bourdon gauges, a fertilizer and chlorine injection system consisting of two piston dosing pumps, and a filtering system consisting of two fil- ters, one of them a $130 \mathrm{~mm}$ disc filter with a $25.4 \mathrm{~mm}$ diameter, and the other a synthetic fabric filter.

Fertirrigation was carried out with an organicmineral fertilizer applied via irrigation water. The product was in liquid form, with a $1.27 \mathrm{~g} \mathrm{~cm}^{-3}$ density. According to the manufacturer, the fertilizer's composition was $25 \%$ organic matter, $3 \%$ total nitrogen, and $9 \%$ potassium in the form of $\mathrm{K}_{2} \mathrm{O}$. The bodies for both filters were identical, made of plastic, and the only difference between them was the filter element. This procedure ensured functional similarity between the filters. The nonwoven synthetic fabric-type filter was selected based on the procedure by Scatolini (2001). The specifications possessed by the non-woven synthetic fabric used as filtering medium were: normal permeability $0.5 \mathrm{~cm} \mathrm{~s}^{-1}$, permittivity $1.6 \mathrm{~s}^{-1}$, pore openings $0.150 \mathrm{~mm}$, grammage $380 \mathrm{~g}$ $\mathrm{m}^{-2}$, and thickness $3.8 \mathrm{~mm}$. The pump/motor assembly supplied both filters installed in parallel, therefore under the same head loss conditions. The mean flow through each filter was $0.6 \mathrm{~m}^{3} \mathrm{~h}^{-1} ; 69.94 \mathrm{kPa}$ pressure regulators were installed in order to ensure equal pressure in the filters.

The irrigation cycles were established by means of an irrigation controlling device programmed to trigger the system twice a day, early in the morning and by the end of the afternoon. The irrigation period lasted two hours, and the fertilizers were applied in the main line of the system for one and a half hours, while the application of water containing chlorine was completed during the remaining time. The source of chlorine consisted of sodium hypochlorite (12\%). A required chlorine concentration value of $2 \mathrm{mg} \mathrm{L}^{-1}$ in the drip line was adopted. A concentration of 1 to $2 \mathrm{mg} \mathrm{L}^{-1}$ free chlorine was used in the drip lines for the preventive control of clogging related to the control of algae and slime (English, 1985).

Water samplings from the reservoir were taken in the four seasons of the year between 2001 and 2002. During the field samplings, factors related to the quality of trickle irrigation water that could cause drip emitter clogging were determined, such as: $\mathrm{pH}$, suspension solids (Ss), turbidity, electric conductivity (Ec), dissolved solids, total iron $(\mathrm{Fe})$, hydrogen sulfides $\left(\mathrm{H}_{2} \mathrm{~S}\right)$, manganese $(\mathrm{Mn})$, hardness, Langelier index, and concentrations of algae and bacteria. The collection site was in the main irrigation line, downstream from the pumping system, but upstream from the fertilizer injection system. Water classification for the trickle irrigation system with regard to clogging problems due to physical, chemical, and biological factors followed recommendations by Nakayama \& Bucks (1986).

To determine the values of water-dissolved solids, a proportionality ratio between the electric conductivity values measured for that parameter was used. The ratio for dissolved solids determination is given by $\mathrm{DS}=$ $\mathrm{Ec} \times 640$, where DS stands for dissolved solids $\left(\mathrm{mg} \mathrm{L}^{-1}\right)$ and $\mathrm{Ec}$ is electric conductivity $\left.(\mathrm{mS} \mathrm{cm})^{-1}\right)$. 
In the analysis of clogging problems related to bicarbonate $(\mathrm{Bc})$, the Langelier saturation index was used to analyze $\mathrm{CaCO}_{3}$ precipitation risk, as proposed by Nakayama \& Bucks (1986). This index indicates the precipitation tendency of $\mathrm{CaCO}_{3}$ that is present in irrigation water; positive values indicate a tendency for $\mathrm{CaCO}_{3}$ to precipitate, while negative values indicate that $\mathrm{CaCO}_{3}$ is maintained in the solution (Ayers \& Westcot, 1991). The criterion proposed by Pitts et al. (1990) was used to classify the reservoir water with respect to hardness. Bacterial populations were determined by the counting method in a Petri dish, using agar (tryptone, glucose, and yeast extract) as a culture medium, with a counting time of 48 h (APHA, 1992a). The algae were counted by the Sedgwick-Rafter method, according to the "Standard Methods for the Examination of Water and Wastewater" (APHA, 1985). To monitor head loss at the filters, differential pressure transducers were used, with pressure gauges located before and after the filters. The data were stored in a data acquisition system (datalogger). The head loss increase caused by retention of impurities in the filters was determined based on the volume filtered. Filter cleaning was performed when a pressure differential higher than $40 \mathrm{kPa}$ was reached.

\section{RESULTS AND DISCUSSION}

In the first collection period, the water from the reservoir showed good quality to supply a drip irrigation system (Table 1). Except for some chemical factors that presented a medium emitter-clogging risk $(\mathrm{pH}$, total iron concentration, and sulfides), all other water quality parameters analyzed resulted in values that did not present a clogging risk to drip emitters, according to the classification by Nakayama \& Bucks (1986).

According to Pitts et al. (1990), the hardness values for the reservoir water in that period are considered as having a low clogging potential with regard to the for- mation of $\mathrm{CaCO}_{3}$ precipitates. This can also be confirmed through the results of calculated Langelier index values, which were always negative, indicating that no precipitate formation problems exist according to Ayers \& Westcot (1991).

Similarly as for the concentration of suspended solids, the turbidity values obtained were also low (between 3.88 and 1.82), indicating that in that period the water presented good quality. The electric conductivity values indicated that the water used for irrigation had a very low salinity and varied very little during the first water collection period. This is confirmed by the values of dissolved solids in the water, which showed a low clogging risk.

The high standard deviation values, and especially the high coefficient of variation values indicate that there was great variation in the amount of algae present in the water, with highest and lowest concentration values of 1,295 and 165 algae $\mathrm{cm}^{-3}$, respectively.

In the second collection period, the quality of the reservoir water presented significant changes in several parameters analyzed. These changes caused a drop in irrigation water quality, especially evidenced by an increase in the concentration of total suspended solids, turbidity, iron, sulfides, and algae. Despite the increase in the mean values for these parameters, only the increase in concentration of sulfides increased the clogging risk for the emitters from medium to high. The other values for the parameters analyzed did not produce a change in clogging risk class. Irrigation water turbidity showed the same tendency as that observed for suspension solids, that is, there was an increase in mean turbidity value and a slight decrease in variability of the data as compared to the previous period (Table 2).

Water electric conductivity decreased in the second period in relation to the first, and its values were more stable than those previously observed, showing a low clogging risk (Table 2) and following the same tendency of the concentration of dissolved solids.

Table 1 - Physical, chemical, and biological factors of irrigation water during the first stage.

\begin{tabular}{|c|c|c|c|c|c|c|c|c|c|c|c|}
\hline & \multicolumn{11}{|c|}{ Irrigation Water Parameters } \\
\hline & \multicolumn{2}{|c|}{ Physical } & \multicolumn{7}{|c|}{ Chemical } & \multicolumn{2}{|c|}{ Biological } \\
\hline & SS & Turbidity & $\mathrm{pH}$ & Iron & Sulfides & E. C. ${ }^{4}$ & $\begin{array}{c}\text { Dissolved } \\
\text { Solids }\end{array}$ & Hardness & Langelier Index & Algae & Bacteria \\
\hline & $\operatorname{mg~L}{ }^{-1}$ & NTU & & -.-- mg & $L^{-1} \cdots$ & $\mathrm{mS} \mathrm{cm}{ }^{-1}$ & $\cdots--m$ & $\mathrm{~g} \mathrm{~L}^{-1}-\cdots$ & & no. $\mathrm{cm}^{-3}$ & no. $\mathrm{cm}^{-3}$ \\
\hline Range & $1.0-5.0$ & $1.82-3.88$ & $7.1-7.5$ & $0.4-1.0$ & $1.0-2.0$ & $0.045-0.076$ & $28.8-48.64$ & $20.22-26.63$ & $(-2.07)-(-1.39)$ & $165-1295$ & $270-6500$ \\
\hline Mean & 2.67 & 2.83 & 7.33 & 0.52 & 1.10 & 0.06 & 37.70 & 22.93 & -1.95 & 497 & 2438 \\
\hline Deviation $^{1}$ & 1.51 & 0.68 & 0.23 & 0.18 & 0.32 & 0.01 & 6.33 & 2.14 & 0.30 & 345 & 2812 \\
\hline Coeff. Var. $^{2}(\%)$ & 56.46 & 24.18 & 3.09 & 33.68 & 28.75 & 16.80 & 16.79 & 9.32 & 15.57 & 69.46 & 115.36 \\
\hline Clogging risk ${ }^{3}$ & $\mathrm{~L}$ & $\mathrm{~N} / \mathrm{R}$ & $\mathrm{M}$ & M & $\mathrm{M}$ & $\mathrm{N} / \mathrm{R}$ & $\mathrm{L}$ & $\mathrm{N} / \mathrm{R}$ & $\mathrm{N} / \mathrm{R}$ & $\mathrm{N} / \mathrm{R}$ & $\mathrm{L}$ \\
\hline
\end{tabular}

${ }^{1}$ Standard Deviation of the mean; ${ }^{2}$ Coefficient of variation; ${ }^{3} \mathrm{~L}$ - low risk; M - medium risk; H - high risk; N/R - not rated; ${ }^{4}$ Electric conductivity. 
Hardness of the reservoir water in the second collection period presented a decline in its mean value and a smaller variation of values when compared with those obtained previously. The water still presented a low clogging potential with regard to the formation of $\mathrm{CaCO} 3$ precipitates, according to the classification by Pitts et al. (1990). The mean Langelier Index obtained was identical to the previous, with a value of -1.95 . However, higher standard deviation (0.42) and coefficient of variation values (21.53\%) were obtained (Table 2$)$. An increase in the amount of algae present in the water and a substancial decrease in the variation of measurements were observed. Probably, the natural increase in temperature and the number of daily hours of sun could explain this change in relation to the previous stage.

In the third collection period an increase in the mean values of physical parameters occurred (suspended solids and turbidity), with a decline in the chemical (except concentration of sulfides and Langelier index) and biological parameters (Table 3). The changes, however, were not substantial, so that the clogging risk classification for each factor analyzed remained unchanged.
In the last period, except for water turbidity, $\mathrm{pH}$, and iron concentration, there was an increase in all analyzed water quality parameters (Table 4). However, the only change that occurred in relation to the clogging risk of drip emitters was a risk decrease with regard to $\mathrm{pH}$.

The quality of the water used for irrigation in the drip irrigation system varied during the different seasons of the year, and the potential clogging risk of drip emitters was medium or high only in relation to chemical parameters (iron, sulfides, and $\mathrm{pH}$ ). The $\mathrm{pH}$ values found through this research are similar to those obtained by Testezlaf el al. (1994), who verified the potential for using water from reservoirs and rivers in drip irrigation systems at agricultural properties that produce vegetables in the region of Campinas. They observed that, among 27 water sources analyzed, $88.9 \%$ showed an alkaline $\mathrm{pH}$ and a moderate risk of clogging according to the same classification adopted in this research.

Problems with bacterium-iron interactions have occurred at iron concentrations as low as $0.1 \mathrm{mg} \mathrm{L}^{-1}$. Contents of this ion higher than $0.2 \mathrm{mg} \mathrm{L}^{-1}$ are considered as presenting a significant clogging risk (English, 1985).

Table 2 - Physical, chemical, and biological factors of irrigation water during the second stage.

\begin{tabular}{|c|c|c|c|c|c|c|c|c|c|c|c|}
\hline & \multicolumn{11}{|c|}{ Irrigation Water Parameters } \\
\hline & \multicolumn{2}{|c|}{ Physical } & \multicolumn{7}{|c|}{ Chemical } & \multicolumn{2}{|c|}{ Biological } \\
\hline & SS & Turbidity & $\mathrm{pH}$ & Iron & Sulfides & E. C. ${ }^{4}$ & $\begin{array}{l}\text { Dissolved } \\
\text { Solids }\end{array}$ & Hardness & Langelier Index & Algae & Bacteria \\
\hline & $\mathrm{mg} \mathrm{L}^{-1}$ & NTU & & ----- mg & $\mathrm{L}^{-1}----$ & $\mathrm{mS} \mathrm{cm} \mathrm{cm}^{-1}$ & $-----m_{\xi}$ & $L^{-1}---$ & & no. $\mathrm{cm}^{-3}$ & no. $\mathrm{cm}^{-3}$ \\
\hline Range & $8.5-13.5$ & $5.19-11.9$ & $6.4-8.1$ & $0.5-1.7$ & $1.0-9.0$ & $0.044-0.06$ & $26.8-38.40$ & $20.2-22.7$ & $(-2.62)-(-1.90)$ & $930-1820$ & $1-7000$ \\
\hline Mean & 10.96 & 8.27 & 7.39 & 1.10 & 2.42 & 0.05 & 32.21 & 20.71 & -1.95 & 1377 & 1202 \\
\hline Deviation $^{1}$ & 1.37 & 1.91 & 0.46 & 0.38 & 2.27 & 0.01 & 3.68 & 1.04 & 0.42 & 287 & 2065 \\
\hline Coeff. Var. $^{2}(\%)$ & 12.53 & 23.13 & 6.23 & 34.89 & 94.13 & 9.96 & 11.42 & 5.00 & 21.53 & 20.88 & 171.81 \\
\hline Clogging risk $^{3}$ & $\mathrm{~L}$ & $\mathrm{~N} / \mathrm{R}$ & M & M & $\mathrm{H}$ & $\mathrm{N} / \mathrm{R}$ & $\mathrm{L}$ & $\mathrm{N} / \mathrm{R}$ & $\mathrm{N} / \mathrm{R}$ & $\mathrm{N} / \mathrm{R}$ & $\mathrm{L}$ \\
\hline
\end{tabular}

${ }^{1}$ Standard Deviation of the mean; ${ }^{2}$ Coefficient of variation; ${ }^{3} \mathrm{~L}$ - low risk; M - medium risk; H - high risk; N/R - not rated; ${ }^{4}$ Electric conductivity.

Table 3 - Physical, chemical, and biological factors of irrigation water during the third stage.

\begin{tabular}{|c|c|c|c|c|c|c|c|c|c|c|c|}
\hline & \multicolumn{11}{|c|}{ Irrigation Water Parameters } \\
\hline & \multicolumn{2}{|c|}{ Physical } & \multicolumn{7}{|c|}{ Chemical } & \multicolumn{2}{|c|}{ Biological } \\
\hline & SS & Turbidity & $\mathrm{pH}$ & Iron & Sulfides & E. C. ${ }^{4}$ & $\begin{array}{l}\text { Dissolved } \\
\text { Solids }\end{array}$ & Hardness & Langelier Index & Algae & $\begin{array}{c}\text { Bacteri- } \\
\text { a }\end{array}$ \\
\hline & $\mathrm{mg} \mathrm{L}^{-1}$ & NTU & & -..- mg & $\mathrm{g} \mathrm{L}^{-1}-\cdots$ & $\mathrm{mS} \mathrm{cm}{ }^{-1}$ & -.--- mg & $\operatorname{g~L}^{-1}-\cdots$ & & no. $\mathrm{cm}^{-3}$ & ${ }^{3}$ no. $\mathrm{cm}^{-3}$ \\
\hline Range & $12.5-19$ & $7.12-16.9$ & $6.8-7.8$ & $0.2-1.0$ & $1.0-5.0$ & $0.042-0.056$ & $26.88-35.84$ & $13.77-19.29$ & $9(-2.96)-(-0.98)$ & $120-705$ & $5 \quad 10-760$ \\
\hline Mean & 17.61 & 11.30 & 7.13 & 0.74 & 2.83 & 0.05 & 31.72 & 17.96 & -2.23 & 459 & 223 \\
\hline Deviation $^{1}$ & 4.17 & 2.93 & 0.42 & 0.26 & 1.17 & 0.01 & 2.64 & 1.96 & 0.66 & 179 & 236 \\
\hline Coeff. Var. $^{2}(\%)$ & 23.66 & 25.95 & 5.86 & 34.97 & 41.39 & 8.33 & 8.33 & 10.90 & 29.76 & 38.97 & 105.74 \\
\hline Clogging risk ${ }^{3}$ & $\mathrm{~L}$ & $\mathrm{~N} / \mathrm{R}$ & M & M & $\mathrm{H}$ & $\mathrm{N} / \mathrm{R}$ & $\mathrm{L}$ & $\mathrm{N} / \mathrm{R}$ & $\mathrm{N} / \mathrm{R}$ & $\mathrm{N} / \mathrm{R}$ & $\mathrm{L}$ \\
\hline
\end{tabular}


Table 4 - Physical, chemical, and biological factors of irrigation water during the fourth stage.

\begin{tabular}{|c|c|c|c|c|c|c|c|c|c|c|c|}
\hline & \multicolumn{11}{|c|}{ Irrigation Water Parameters } \\
\hline & \multicolumn{2}{|c|}{ Physical } & \multicolumn{7}{|c|}{ Chemical } & \multicolumn{2}{|c|}{ Biological } \\
\hline & SS & Turbidity & $\mathrm{pH}$ & Iron & Sulfides & E. C. ${ }^{4}$ & $\begin{array}{l}\text { Dissolved } \\
\text { Solids }\end{array}$ & Hardness & Langelier Index & Algae & Bacteria \\
\hline & $\mathrm{mg} \mathrm{L}^{-1}$ & NTU & & ---- mg & $\mathrm{L}^{-1}----$ & $\mathrm{mS} \mathrm{cm} \mathrm{cm}^{-1}$ & ----- mg & g $L^{-1}---$ & & no. $\mathrm{cm}^{-3}$ & no. $\mathrm{cm}^{-3}$ \\
\hline Range & $16.0-23.5$ & $7.45-14.5$ & $6.6-7.3$ & $0.0-1.0$ & $2.0-16$ & $0.032-0.090$ & $20.48-57.60$ & $20.68-22.96$ & $(-3.63)-(-2.07)$ & $205-950$ & $200-5400$ \\
\hline Mean & 19.7 & 10.14 & 6.88 & 0.48 & 3.50 & 0.059 & 38.02 & 21.25 & -2.566 & 512 & 1702 \\
\hline Deviation $^{1}$ & 2.51 & 2.23 & 0.19 & 0.32 & 4.40 & 0.017 & 10.65 & 0.72 & 0.425 & 216 & 1798 \\
\hline Coeff. Var. ${ }^{2}(\%)$ & 12.78 & 21.97 & 2.89 & 66.46 & 125.81 & 28.00 & 28.00 & 3.37 & 16.57 & 42.12 & 105.62 \\
\hline Clogging risk ${ }^{3}$ & $\mathrm{~L}$ & $\mathrm{~N} / \mathrm{R}$ & M & M & $\mathrm{H}$ & $\mathrm{N} / \mathrm{R}$ & $\mathrm{L}$ & $\mathrm{N} / \mathrm{R}$ & $\mathrm{N} / \mathrm{R}$ & $\mathrm{N} / \mathrm{R}$ & $\mathrm{L}$ \\
\hline
\end{tabular}

${ }^{1}$ Standard Deviation of the mean; ${ }^{2}$ Coefficient of variation; ${ }^{3} \mathrm{~L}$ - low risk; $\mathrm{M}$ - medium risk; H - high risk; N/R - not rated; ${ }^{4}$ Electric conductivity.

Precipitated iron develops a red incrustation, which can adhere to the PVC piping and clog the emitters. Some filamentous bacteria, such as Gallionella, Crenothrix, and Leptothrix oxidize $\mathrm{Fe}^{+2}$, transforming it into $\mathrm{Fe}^{+3}$ which can precipitate and cause clogging (Ford \& Tucker, 1986; Pizarro, 1996). These bacteria are important both economically and sanitarily, causing the formation of iron incrustations inside pipes or homes, as well as by precipitating ferric hydroxide into waters that are rich in this element. They even form extensive geological deposits of iron, and in pipes they constitute frequent causes of obstructions, in addition to making water take on a brownreddish coloration. Some types of disinfectants, such as chlorine and copper sulfate, have been used to control these bacteria. The latter has been successfully used at dose rates of 0.3 to $0.5 \mathrm{mg} \mathrm{L}^{-1}$ for the control of iron bacteria, such as Crenothrix (White, 1986).

The concentrations of algae and bacteria showed high coefficients of variation during each season of the year, as well as variations between seasons. The dynamic changes in algae populations can represent a hazard to the system if an efficient treatment of irrigation water is not put into action, and indicate great sensitivity of these organisms in relation to variations in water quality. The seasonal variations of algal biomass in tropical regions, where light and water temperature do not change much throughout the year, are due to the effects of rains or drought, and essentially to the action of winds. The coincidence between a slight decrease in temperature and an increase in the intensity and duration of winds can bring about water circulation at greater depths, and consequently cause a sudden variation in algae concentration. In quantitative studies on algae, it is necessary to take into account that the spatial distribution of algal populations is not uniform and that variations, both seasonal and spatial, can be considerable. There is no universal sample-collection method that would ensure the presence of all forms of phytoplankton organisms, since some algal species show great diversity in size, sample, and mobility (Di Bernardo, 1995).
Rapid changes in bacterial concentration values were also verified. These sharp changes were detected through variations in the reservoir water measurements made in the laboratory. The sharp variations in bacterial growth are due to different conditions in the environment, such as temperature, $\mathrm{pH}$, and oxygen and nutrient requirements (Soares \& Maia, 1999). For most bacteria, the optimum $\mathrm{pH}$ for growth occurs between 6.5 and 7.5. The water reservoir $\mathrm{pH}$ varied, on average, from 7.39 (second collection period) to 6.88 (third collection period). When sharp changes in biological parameter values occur due to environment-related factors, the filtering efficiency of trickle irrigation systems can become compromised, with the consequent occurrence of emitter clogging problems (Nakayama \& Bucks, 1991).

Water hardness showed a low clogging potential in relation to the formation of $\mathrm{CaCO}_{3}$ precipitates in all seasons of the year. This can be confirmed by the Langelier Index, which was always negative during the year.

The Langelier Saturation Index (SI), determined based on the $\mathrm{Ca}^{+2}, \mathrm{Mg}^{+2}, \mathrm{HCO}_{3}^{-}$, and $\mathrm{CO}_{3}^{2-}$ contents at a given concentration of ions calcium and bicarbonate, $\mathrm{pH}_{\mathrm{c}}$, and at the measured $\mathrm{pH}$ value, was used to provide a systematic approximation for determination of the risk of formation of calcium carbonate precipitates (United States, 1965). Manganese concentration values below the limit of detection of the equipment were always found in the reservoir water for all samples collected in the four periods.

A constant growth in mean values was observed for both turbidity and concentration of suspended solids in the water from the irrigation reservoir. Even with a growth of about nine times from the first to the fourth stage, on average, the concentration of suspended solids did not reach magnitudes high enough to attain medium to high emitter clogging risks, according to Nakayama \& Bucks (1986) classification. 


\section{Correlation between physical and biological param- eters}

A correlation analysis was made between physical and biological parameters. Equations showing the best coefficients of regression were obtained for the following parameters: turbidity in relation to suspended solids (Figure 1), suspended solids in relation to turbidity (Figure 2), and algae in relation to suspended solids (Figure 3 ).

Turbidity is a suspended-solids indicator, due to the dispersion of light beams caused by the presence of particles in suspension, such as silt, sand, colloidal masses, microorganisms, and so forth. (Branco, 1986). However, turbidity alone is not a precise parameter for determination of the degree of emitter clogging risk in surface water sources (Pitts et al., 1990). This physical parameter should be analyzed jointly in a filtering test in the laboratory to be able to measure emitter clogging risk potential (Gilbert \& Ford, 1986).

There were high-coefficient correlations between total suspended solids concentration and algae, such as: 0.93 between the total number of particles and algae concentration; 0.90 between the total number of particles in the size range from 2 to $4 \mu \mathrm{m}$ and the total concentra-

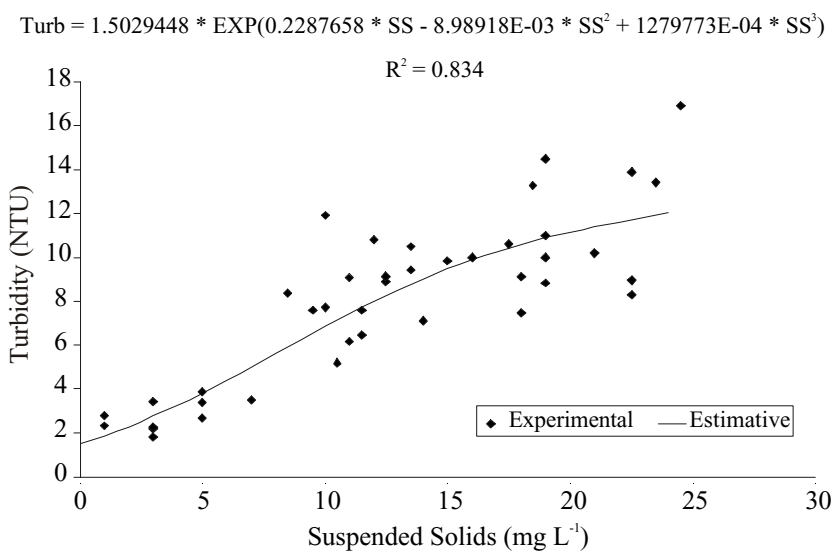

Figure 1 - Correlation between turbidity (Turb) and suspended solids (SS).

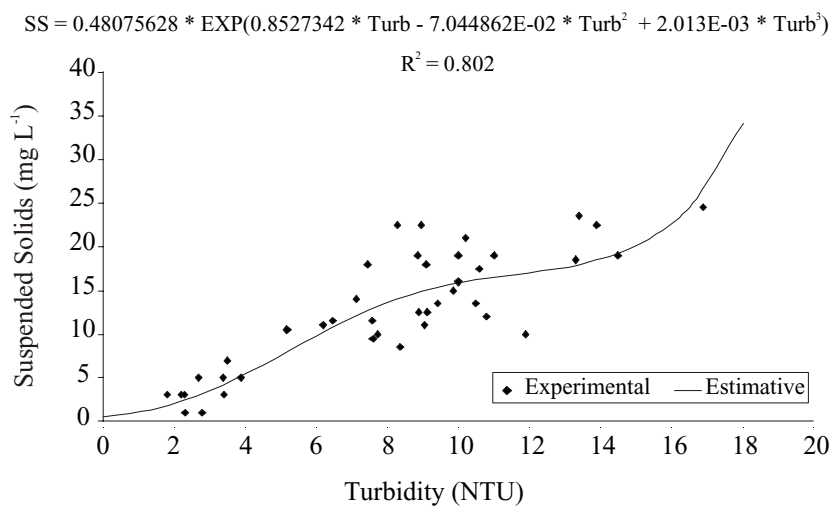

Figure 2 - Correlation between suspended solids (SS) and turbidity (Turb). tion of algae; 0.93 and 0.96 , between the number of particles in the size ranges from 10 to $15 \mu \mathrm{m}$ and from 15 to $20 \mu \mathrm{m}$, respectively, and green algae concentration (Silverman et al., 1983). The same authors mentioned that algae are directly responsible for increases in turbidity.

Since algae behave in water as particles in suspension, they may constitute a factor directly responsible for turbidity. Especially in cases where the algal bloom phenomenon occurs, the turbidity caused by algae may reach very high values, preventing light from penetrating but a few centimeters into the mass of water. In addition, in the presence of a large amount of algae containing green, bluish, brown, or reddish pigmentation, apparent water coloration phenomena may occur. This coloration, when produced by small flagellates such as Chlamydomonas and others, gives rise to problems that are sometimes difficult to solve, especially when a good coagulation and filtration system is not available (White, 1986).

\section{Influence of Fertirrigation on irrigation water quality}

Some analyses were carried out beginning in the middle of the third stage, in order to verify the influence of fertilizer injection on irrigation water quality. The only analyses performed were for water turbidity and concentration of suspended solids. The water sample collection sites were: Upstream from injection (corresponding to reservoir water), downstream from injection (water arriving at the filters), and water in the reservoir tank containing the fertilizer solution. The samples were collected simultaneously.

Figures 4 and 5 show results obtained for both turbidity and suspended solids. The analyses were performed in the period from 14 to 28 March 2002, during the third stage. Figure 4 displays a variation in turbidity for the water sampled from the fertilizer solution reservoir. In other words, a continuous change in water quality occurred in the fertilizer tank. In the period from days 14 to 26, turbidity increased from 1.36 NTU to 13 NTU.

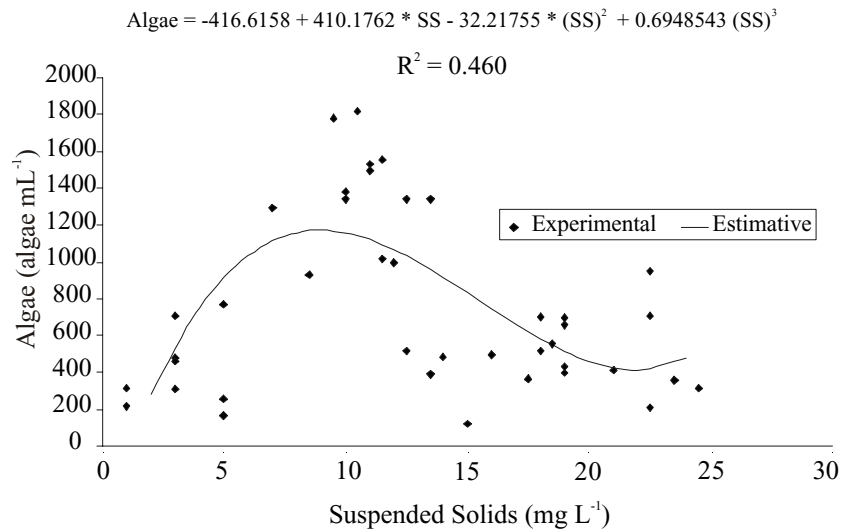

Figure 3 - Correlation between amount of algae (algae) and suspended solids (SS).

Sci. Agric. (Piracicaba, Braz.), v.61, n.6, p.563-572, Nov./Dec. 2004 
During the period when the assays were carried out, it was possible to visually notice the development of algae inside the tank, which could be related to this rapid increase in turbidity values. Turbidity downstream from the fertilizer injection site was always higher than the measurement taken upstream. This means that the water which effectively arrived at the filters had its quality depreciated in relation to the water that supplied the irrigation system.

Similarly as verified for turbidity, there was a continuous growth in the concentration of suspended solids inside the fertilizer tank (Figure 5). The water in the reservoir was also affected by the influence of fertirrigation, since the samples collected after fertilizer injection showed a greater concentration of suspended solids than those collected before that point, except on March 182002.

Figures 6 and 7 contain results of analyses performed in the fourth and last stage of the experiment to evaluate the influence of fertirrigation on the quality of water used for irrigation. Measurements made down-

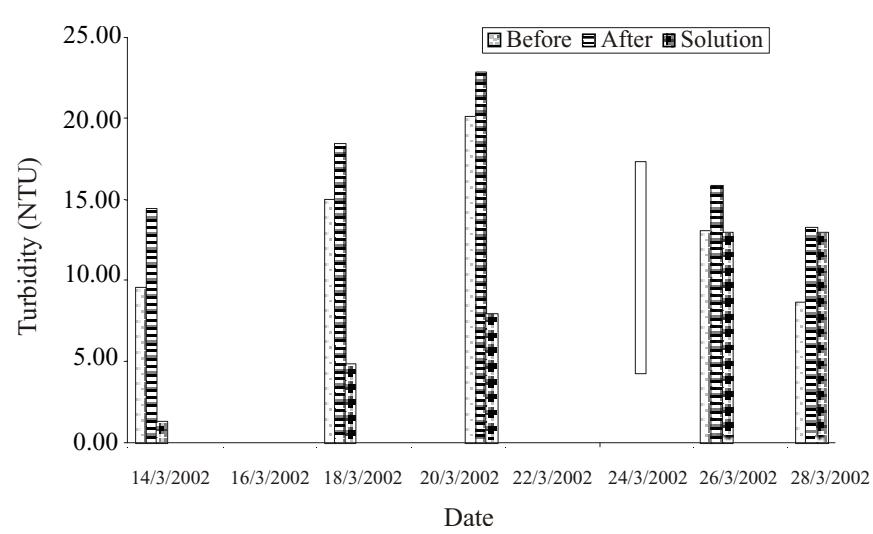

Figure 4 - Variation in turbidity of water sampled upstream and downstream from the fertilizer injection site, and in the fertilizer solution proper, during the third research stage.

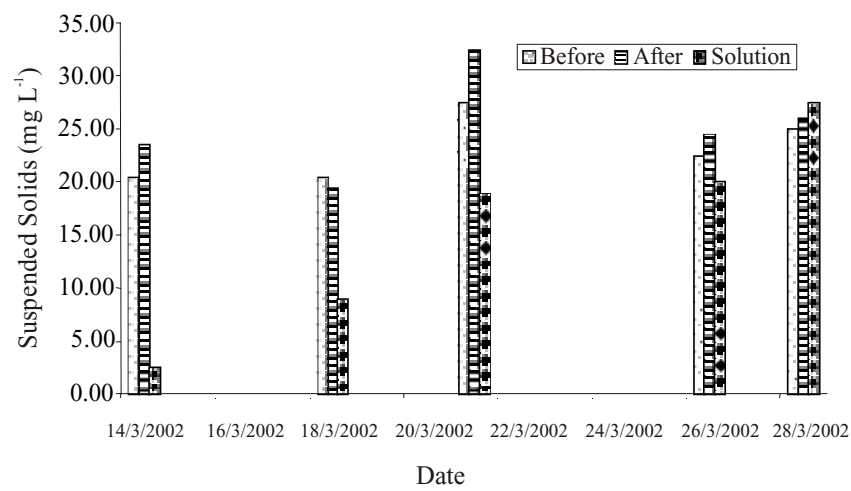

Figure 5 - Variation in suspended solids concentration of water sampled upstream and downstream from the fertilizer injection site, and in the fertilizer solution proper, during the third research stage. stream from the fertilizer injection point showed values higher than those obtained in samples collected upstream of the fertilizer injection point in six of ten assays (Figure 6). In addition, high variability can be noticed in the data corresponding to the fertilizer solution itself, indicating that variation in water quality occurred with time inside the solution reservoir tank. In the tenth assay, the turbidity value for the reservoir water was higher than the values measured either before or after the injection point. A rapid development of algae and bacteria probably occurred because of the abundance of nutrients in the solution, which resulted in increased water turbidity.

There was some similarity between variation in water turbidity in the fertilizer solution and variation in the concentration of total suspended solids. Turbidity in the fertilizer solution was certainly much more affected by the development of algae and bacteria inside the tank than the concentration of suspended solids. The concentration of suspension solids in the solution never showed a value near those obtained in the two other collection points. The total suspended solids concentration in the

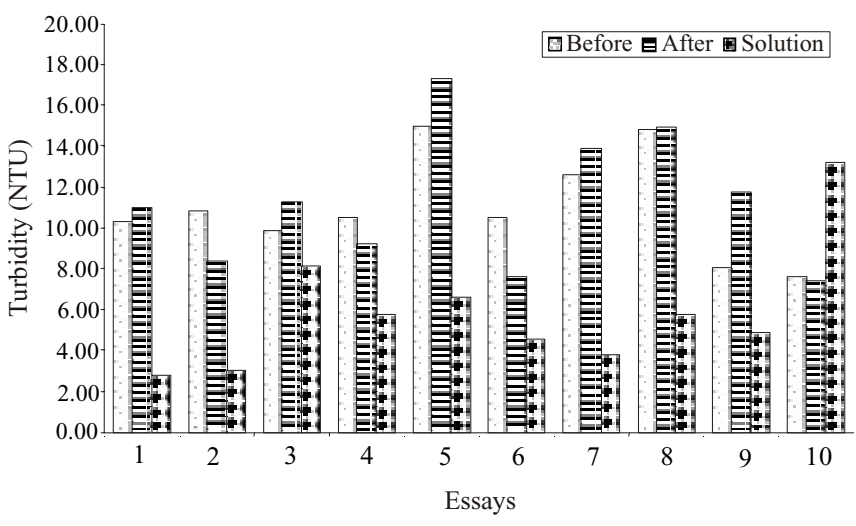

Figure 6 - Variation in water turbidity upstream and downstream from the fertilizer injection site, and in the fertilizer solution proper, during the fourth research stage.

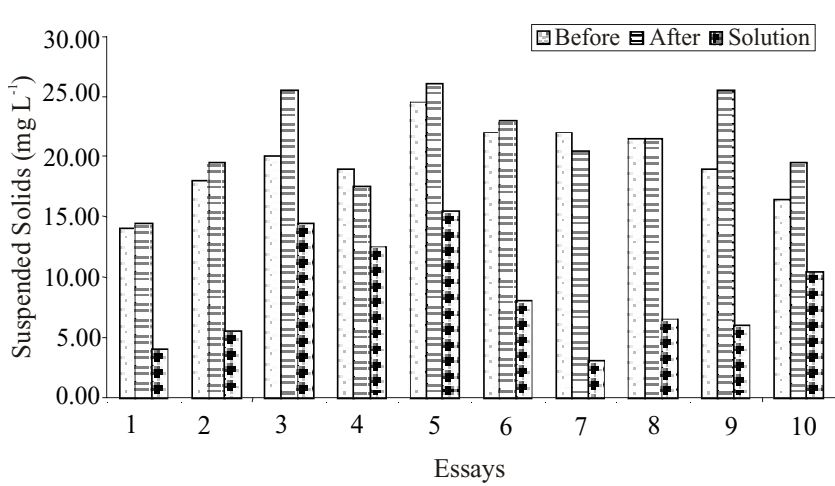

Figure 7 - Variation in suspended solids concentration of water sampled upstream and downstream from the fertilizer injection site, and in the fertilizer solution proper, during the fourth research stage. 
water, measured after the fertilizer injection point, was equal or higher than the concentration obtained before that point in 8 of the 10 assays conducted at that stage (Figure 7).

In face of the results obtained in the five final assays of the third stage and in all those conducted in the fourth, it can be stated that an influence of fertirrigation on irrigation water quality exists, as evidenced by the increase in both turbidity and concentration of suspension solids in the water downstream from the point where fertilizers were introduced into the irrigation water.

\section{Effect of chlorination on filters}

Water samples were collected downstream from the filters that received chlorination to determine the concentrations of free chlorine, and thereby to compare the filter elements with regard to where the greatest consumption occurred. The concentrations were calculated to provide approximately $2 \mathrm{mg} \mathrm{L}^{-1}$ free chlorine after the filters, according to the methodology adopted in this research.

The graph in Figure 8 presents the mean chlorine concentration results in the four stages of the research. In the first two stages, the free chlorine concentration means were higher, and a reduction occurred in the other two for both filters. Variations in free chlorine occurred due to variation in water quality along the year with regard to the concentrations of algae and bacteria.

There are a series of factors that influence the bactericidal effect of chlorine, among which are the content of oxidable organic matter, concentration of microorganisms, water $\mathrm{pH}$, temperature, contact time, and water chemical composition (presence of iron salts, ammonia, etc.) (Soares \& Maia, 1999). The concentrations of free chlorine were always higher in the disc filter effluents, in all stages. This fact occurred because the nonwoven synthetic fabric filter element has greater permeability, thus causing greater retention of impurities, and consequently greater free chlorine consumption.

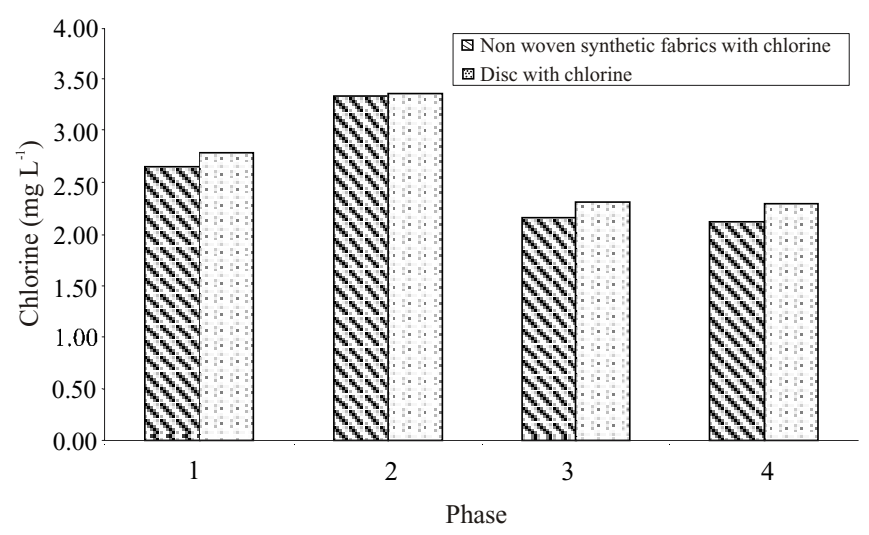

Figure 8 - Mean concentration of free chlorine in fabric and disc filters during 4 stages.

\section{Head loss evolution versus volume filtered into the fil- tering systems.}

Figures 9, 10, 11, and 12 contain results of four research stages with regard to head loss evolution at both irrigation filters with time. Head loss showed a continuous growth until a moment when an abrupt drop was verified; next, a new growth occurred followed by another decline, and so on. Sharper declines, in which head loss returned to values below $20 \mathrm{kPa}$ represent moments when the filter element was washed, whereas smaller intensity decreases only represent the transition between one irrigation shift and the next. Head loss evolution in the fabric filter was much faster than that observed in the disc filter during the first stage (Figure 9). In this initial experimentation period, reservoir water quality was always very good, with low concentrations of suspended solids, algae, and bacteria (Table 2). Starting at the fourth filter element wash (with a filtered volume in the order of 32.0 $\mathrm{m}^{3}$ ), head loss increase in the fabric filter became more expressive. During that stage, it was not necessary to perform any cleaning operation in the disc filters; the head loss developed at them was nearly stable and always stayed in the interval from 5 to $10 \mathrm{kPa}$.

During the first stage of the research, the fabric filter had to be cleaned fourteen times. The disc filter did not need to be washed. Filter element cleanings were per-

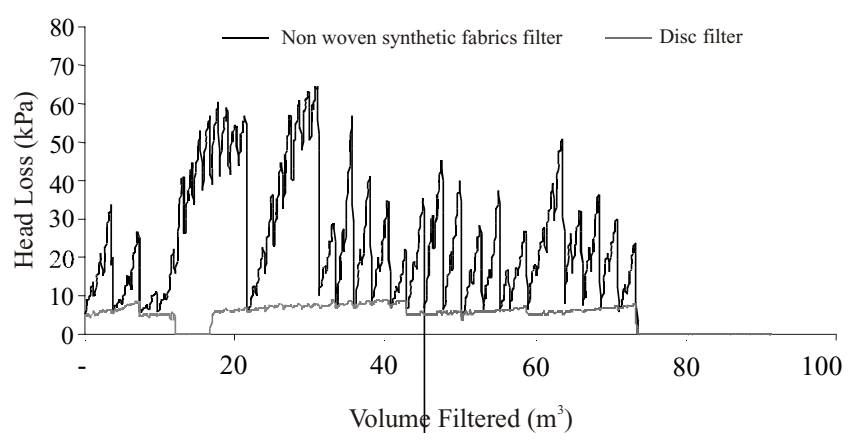

Figure 9 - Head loss variation versus filtered volume for disc and non-woven synthetic fabric filters during the first stage.

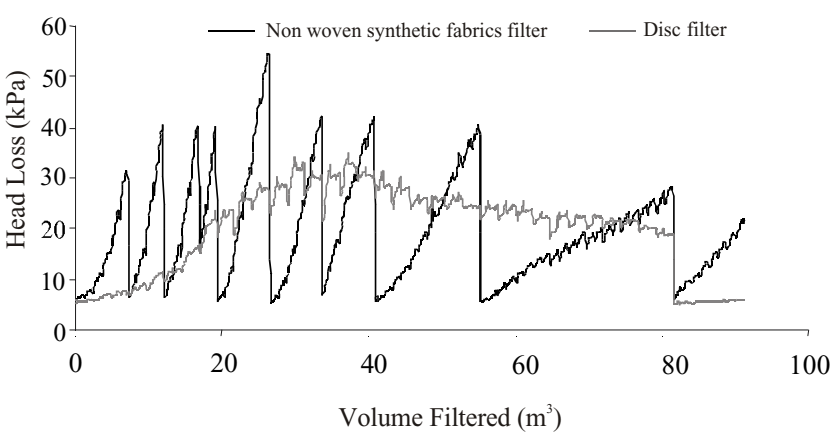

Figure 10 - Head loss variation versus filtered volume for disc and non-woven synthetic fabric filters during the second stage.

Sci. Agric. (Piracicaba, Braz.), v.61, n.6, p.563-572, Nov./Dec. 2004 


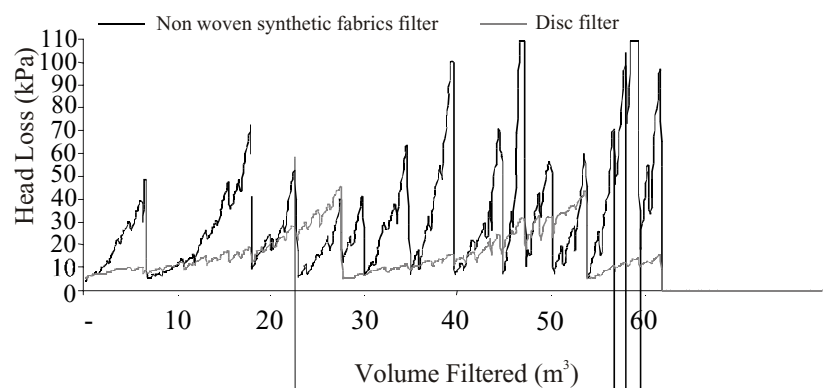

Figure 11 - Head loss variation versus filtered volume for disc and non-woven synthetic fabric filters during the third stage.

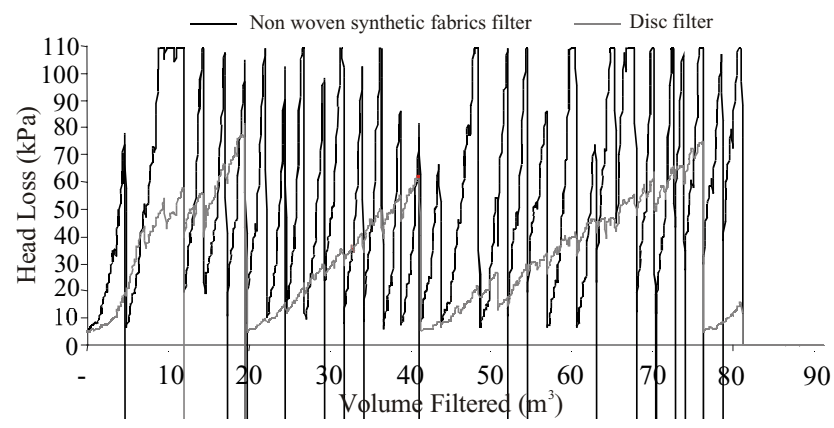

Figure 12 - Head loss variation versus filtered volume for disc and non-woven synthetic fabric filters during the fourth stage.

formed manually between irrigation shifts, with the water normally supplied by the city.

In the second stage (Figure 10), water quality became worse, as evidenced by the increase in mean values obtained for the analyzed concentrations of parameters suspended solids, turbidity, and algae (Table 2). Similarly as observed in the first stage of the research, the head loss evolution developed during the second stage in the fabric filter occurred faster than in the disc filter. Again, the fabric filter showed greater head loss as compared to the disc filter. Eight washes were needed for the fabric filter, while none was needed for the disc filter. As irrigation water quality worsened, head loss ranged from 5 to $35 \mathrm{kPa}$ in the disc filter, and was more commonly between 20 and $30 \mathrm{kPa}$ during the entire second stage.

The trends observed in the first and second stages were repeated in the third stage, that is, more filter cleaning was required because of water quality deterioration. Twelve cleaning operations were performed for the fabric filter, and in some instances head loss achieved values of $100 \mathrm{kPa}$ because of the velocity with which localized losses occurred (Figure 11). Two cleanings were needed for the disc filter during that period.

The worsening in reservoir water quality during the third stage, as evidenced by an increase in the mean concentration of suspension solids and turbidity in the reservoir water (Table 2), caused a fast increase in head loss at the filters. At several moments, head loss in the fabric filter exceeded $50 \mathrm{kPa}$ due to the quickness with which the material suspended in water would cause pore obstruction in the filter elements, since the plan was to clean the filters whenever localized head loss reached 40 $\mathrm{kPa}$.

During the last stage (Figure 12), the mean concentrations of suspended solids and turbidity attained their highest values (Table 2); for this reason, the filters operated under more severe conditions. Similarly as observed in previous stages, the head loss developed in the nonwoven synthetic fabric filter was higher than that developed in the disc filter. At some moments, head loss in the disc filter quickly exceeded the maximum programmed loss of $40 \mathrm{kPa}$. During the period, 23 cleaning operations were needed for the fabric filter, and 3 were needed for the disc filter. The fabric filter's high wash frequency, as well as the high head loss values attained in the disc filter are compatible with the increase in mean concentrations of suspended solids and turbidity for the reservoir water.

After completion of the four research stages, it can be stated that head loss evolution as a function of filtered volume in the non-woven synthetic fabric filter was quicker than in the disc filter. Therefore, a higher number of washes occurred for the synthetic fabric filter. This apparent disadvantage of the fabric filter happens because it presents greater retention of particles suspended in water. The same problem occurred in a study performed by Scatolini (2001), where the author concluded that the faster head loss increase in the non-woven synthetic fabric filter was due to a greater retention of suspended solids that partially obstructed the filtering medium.

Another factor that must be considered is that the structure of the fabric filter has greater effective filtering area than the disc filter; therefore, head loss development is faster in the fabric filter. In their paper, Nakayama and Bucks (1991) reported that when high concentrations of particles in suspension are present in irrigation water, the filtering systems of a trickle irrigation system require more frequent cleaning. The authors suggest that for a better suspended particle removal control, an automatic backwash filter should be used.

\section{CONCLUSION}

The irrigation water biological parameters showed greater variation. Head loss evolution in the nonwoven synthetic fabric and disc filters was influenced by water quality, and this influence was higher in the first filter, resulting in a greate $r$ number of cleaning operations. Future researches involving different types of fabric, thicknesses, and filtering areas might indicate which are the best specifications for this filter element to be used in trickle irrigation. 


\section{ACKNOWLEDGEMENTS}

To FAPESP for financially supporting the project (Proceeding:00/01292-5) and for scholarships granted (Proceedings: 01/02058-9 and 01/01719-1).

\section{REFERENCES}

ADIN, A.; ALON, G. Mechanisms and process parameters of filter screens. Journal of Irrigation and Drainage Engineering, v.112, p.293-304, 1986

AYRES, R.S.; WESTCOT, D.W. A qualidade da água na agricultura. Campina Grande: UFPB, 1991. 218p.

AMERICAN PUBLIC HEALTH ASSOCIATION. Standard methods for examination of water and wastewater. Washington: APHA, 1992a p.9.32-9.34: Heterotrophic plate count.

AMERICAN PUBLIC HEALTH ASSOCIATION: Standard methods for the examination of water and wastewater. 16. ed. Washington: APHA; AWWA; APCF 1985. 1268p

BRANCO, S. M. Hidrobiologia aplicada à engenharia sanitária. $3^{\text {a }}$ edição. CETESB/ASCETESB, São Paulo/SP, 1986. 640p.

ENGLISH, S.D. Filtration and water treatment for micro-irrigation. In. INTERNACIONAL DRIP/TRICKLE IRRIGATION CONGRESS, 3., Fresno, 1985. Proceedings. St Joseph: ASAE, p.50-57.

DI BERNARDO, L. Algas e suas influências na qualidade das águas e nas tecnologias de tratamento. Rio de Janeiro: ABES; 1995. 140p.

FORD, H.A.; TUCKER, D.P.H. Clogging of drip systems from metabolic products of iron and sulfur bacteria. In: INTERNACIONAL DRIP IRRIGATION CONGRESS, 2., San Diego, 1986. Proceedings. San Diego, 1986. p.212-214

GILBERT, R.G.; FORD, H.W. Operational principles/emitter clogging. In: NAKAYAMA, F.S.; BUCKS, D.A. Trickle irrigation for crop production: Design, operation and management. Amsterdam: Elsevier, 1986. cap.3, p. 142-163.
NAKAYAMA, F.S.; BUCKS, D.A Trickle irrigation for crop production: Design, operation and management. Amsterdam: Elsevier, 1986. 383p

NAKAYAMA, F.S.; BUCKS, D.A. Water quality in drip/trickle irrigation: a review. Irrigation Science, v.12, p.187-192, 1991.

PITTS, D.J.; HAMAN, D.Z.; SMAJSTLA, A.G. Causes and prevention of emitter plugging in microirrigation systems. Gainesville: Florida Cooperative Extension Service, University of Florida, 1990. (Bulletin, 258)

PIZARRO, F. Riegos localizados de alta frequencia. 3.ed. Madrid: Mundi Prensa, 1996. 513p.

SCATOLINI, M.E. Utilização de mantas não tecidas como elemento filtrante em sistemas de irrigação localizada. Tese (Doutorado) - Faculdade de Engenharia Agrícola, Universidade Estadual de Campinas. Campinas, 2001 .

SOARES, J.B.; MAIA, A.C.F. Água: microbiologia e tratamento. Fortaleza: UFC, 1999. 206p.

SILVERMAN, G.S.; NAGY, L.A.; OLSON, B.H. Variations in particulate matter, algae and bacteria in an uncovered, finished-drinking-water Reservoir. Journal of the American Water Works Association, v.75, p.191-195, 1983.

TESTEZLAF, R.; MATSURA, E.E.; ROSTON, D.M.; PAULA JR., D.R.; PATERNIANI, J.E.; RIBEIRO, T.A.P. Potencialidade do uso de irrigação por gotejamento em propriedades agrícolas produtoras de hortaliças da região de Campinas - SP. In: CONGRESSO BRASILEIRO DE IRRIGAÇÃO E DRENAGEM, 10, Salvador, 1994. p.364-371.

UNITED STATES. Department of Agriculture. An index of the tendency of $\mathrm{CaCO}_{3}$ to precipitate from irrigation waters. U.S. Salinity Laboratories. Soil Science Society of America Proceedings, v.29, p.91-92, 1965.

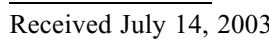

Accepted September 13, 2004 